\title{
Influence of Growth Regulators on Shedding of Broad Bean, Growth, Yield and Seed Quality
}

\author{
A. E. Sharief ${ }^{1}$, M. M. El-hamady² \\ ${ }^{1}$ Department of Agronomy, Faculty of Agriculture, Mansoura University, Egypt. \\ Corresponding Author: Prof. Ali Sharief Agronomy Dept., Fac. of Agric., Mansoura University, Egypt, 35516 El-Mansoura, \\ Egypt Tel: +201222986347 Fax: +2052221688, \\ ${ }^{2}$ Plant Production Department, Faculty of Technology and Development, Zagazig University, Egypt.
}

\begin{abstract}
In order to study the effect of foliar spraying of growth regulators on growth,seed yield and seed quality, two field experiments were conducted at an extensive field during 2014/2015 and 2015/2016 seasons to determine following foliar spraying of Naphthalene Acetic Acid (NAA) concentrations, i.e. 0, 20, 40 and 60 ppm and Kinetin (Kin) concentrations, i.e. 0, 15, 30 and 45 ppm after 35 and 50 days from sown. Accumulative NAA levelsof to $60 \mathrm{ppm}$ significantly increased total chlorophyll, plant height (cm),branches number/plant, number of shedding flowers, shedding \%, pods and seeds number/plant,seedsnumber/pod, seed yield/plant, 100seed weight ( $\mathrm{g}$ ), seed yield (ton/ha) and protein \% in both seasons.Naphthalene Acetic Acid foliar spraying up to 60 ppm exceeded of total chlorophyll, plant height $(\mathrm{cm})$, branchesnumber/plant, number of shedding flowers, podsnumber/plant, seedsnumber/pod, seedsnumber/plant, seed yield $(g) / p l a n t, 100$-seed weight $(g)$, seed yield (ton/ha) and protein \% by 11.47, 23.92, 92.88, 20.53, $11.87,23.48,14.16,24.91,26.15$ and $13.23 \%$, respectively as the average of both seasons. But, reduced the shedding percentage by $11.91 \%$ as the average oftwo seasons. Kinetin (Kin) foliar spraying up to $45 \mathrm{ppm}$ significantly increased total chlorophyll, plant height $(\mathrm{cm})$, number of branches/plant, number of shedding flowers, shedding \%, pods and seeds number/plant,number of seeds/pod, seed yield/plant, 100seed weight (g), seed yield (ton/ha) and protein \% in both seasons. It could be noticed that foliar spraying of Kinetin (Kin) concentrationsup to $45 \mathrm{ppm}$ exceeded total chlorophyll, plant height $(\mathrm{cm})$, branchesnumber/plant, number of shedding flowers, podsnumber/plant, seedsnumber/pod, seedsnumber/plant, seed yield /plant, 100-seed weight ( $\mathrm{g}$ ), seed yield (ton/ha) and protein \% by $12.16,19.39,61.64,5.60,5.56,6.96,5.64,18.75,13.38$ and $4.39 \%$, respectively as average of both seasons. But, reduced the shedding \% by $14.73 \%$ as the average of both seasons.It could be recommended that foliar spraying of Naphthalene Acetic Acid up to $60 \mathrm{ppm}$ and Kin of 45 ppm improved seed yield/ha by $38.2 \%$ compared without foliar application.
\end{abstract}

Keywords - Naphthalene Acetic Acidand Kinetin levels, shedding percentage.

\section{INTRODUCTION}

Vicia faba L.is considered the most significant winter crops for human and animal consumption of the Middle East. The lack of adequate pollination and reduced seed set can be major constraints to yield. Flower drop and seed abortion plus pests are also major constraints to yield. Buds, flowers and immature pods abscission that fail to develop intofully mature pods offaba bean, isconsidered one of the greatestdifficultproblems of yield productivity.This study takes place to investigate the influence of spraying at different concentrations of Naphthalene Acetic Acid (NAA) and Kin on broad bean plants, to study its effects on abortion and drop of flowers, buds and pods, also the impact on vegetative growth and seed yields.Naphthalene Acetic Acid as hormones setthe physiological process of synthetic growth regulators mightimprove growth and development, thereby increased seed yield[1].Foliar spraying of Naphthalene acetic acid is a potential antifungal agent[2].Pant growth regulators are augmentedseedproduction by amassed biological yield. Naphthalene Acetic Acid belongs to synthetic forms of Auxins[3].Spraying of Naphthalene Acetic Acidimproved plant height, fruit set with increases in seed yield/ha[4].Sprayingtwiceof growth regulators improved the number of pods/plant, pod weigh/plant and increased seed yield by $17.7 \%$ compared without growth regulator foliar spraying[5].Application of Amcotone at $600 \mathrm{ppm}$ (NA+NAA), decidedlyaugmented plant height, leaf area index, flowering set, seed yields and its attributes[6].The growth promoter NAA enhanced the mobilization of photo assimilatesinto filling seeds[7].Foliar spraying of Kinetin significantly enhanced plant growth and growth even grown under ecologicalworry. He added that foliar spraying of Kinetinenhanced flowering and delays leaves senescence[8].Foliar application of Vicia fabaplants with indel-3-acetic or gibberellin increased the number of branches/plant and number of pods/plant [9].Plant growth 
substances are enhanced the source-sink relationship and increase the translocation ofphoto-assimilates to sink,formerlyenhanced flower formation, fruit and seed development and improving seed production[10].Foliar sprays with Oraset-x Naphthalene Acetic Acid significantly the superior treatment to produce plants with vigorous vegetative growth, i.e. plant height and number of branches/plant, earliness, highest fruit set percentage, total green yields, number of pods/plant, weight of ten pods, pod characters, weight of 100 green seeds and total protein[11].The highest numbers of shedding flowers and shedding percentage $\%$ were obtained the control. Foliar spraying of GA3 or IAA at $100 \mathrm{ppm}$ exceeded the control by 31.6 and $4.10 \%$, respectively in number of shedding flower/plant[12].Number of pods/plant, pods yield /plant, 100 seed weight and biological yield/plant, protein \%and seed yield/hawere significantly enriched with foliar spraying of $50 \mathrm{mg} / \mathrm{l} \mathrm{IAA}+75 \mathrm{mg} / \mathrm{l}$ Kinetin[13].The objectives of this investigationwas aimed to investigate the effect of foliar spraying of different concentrations of Kinetin,Naphthalene Acetic Acid on growth, shedding percentage, seed yield and its quality.

\section{MATERIALS AND METHODS}

\subsection{Research time and location:}

Two field experiments were conducted in extensive field in Awish El-Hagar village Dakahlia district during $2014 / 2015$ and 2015/2016 seasons to investigate the effect of foliar spraying of different levels of both Naphthalene Acetic Acid (NAA), i.e. 0, 20, 40 and 60 ppm and Kinetin (Kin), i.e. 0, 15, 30 and 45 ppm. The experimental design, layout used was strip plot design with four replicates. Each plot contained of five ridges, 3.5 meters'length and $60 \mathrm{~cm}$ in width. The size of each plot being $10.5 \mathrm{~m}^{2}$. The vertical plots were occupied with the following foliar spraying of Naphthalene Acetic Acid (NAA) rates, i.e. 0, 20, 40 and $60 \mathrm{ppm}$. The horizontal plots were occupied with foliar spraying of Kinetin (Kin) rates, i.e. $0,15,30$ and $45 \mathrm{ppm}$. Growth hormone was sprayed twice at 35 and 50 days from sowing.The experimental units were fertilized with calcium super phosphate $\left(15.5 \% \mathrm{P}_{2} \mathrm{O}_{5}\right)$ at a rate of $240 \mathrm{~kg} / \mathrm{hawas}$ added to the soil during tillage operation and before sowing. 115 $\mathrm{kg} \mathrm{K}_{2} \mathrm{O} /$ ha of potassium sulphate $\left(48 \% \mathrm{~K}_{2} \mathrm{O}\right)$ was added to field in two equal portions, before the first and second irrigation. Nitrogen in the form of ammonium sulphate $(20 \% \mathrm{~N})$ at the rate of $35 \mathrm{~kg} \mathrm{~N} / \mathrm{ha}$ as starter dose and was added before irrigation. However, other agricultural practices were done as commonly followed in the district.Sowing date of faba bean (Cv. Nobaria) was on the $10^{\text {th }}$ of November in both seasons. Faba bean seeds were soaked in water for 24 hours before planting to raise seed germination. Planting was performed on both sides of ridges at $25 \mathrm{~cm}$ between hills. Thinning was done in 21 days from sowing to leave healthy two plants/hill. Hand digging was done every 21 days to control weeds i.e. before, time of irrigations.

\subsection{Studied traits:}

All studied characteristics were applied to harvest time. From each plot, ten guarded plantswere booked from the outer ridges from each sub plot to estimate:1.Total chlorophyll (SPAD): Chlorophyll content in leaf samples was assessed by SPAD-502 (Minolta Co. Ltd., Osaka, Japan). 2. Plant height $(\mathrm{cm})$ : It was measured for each plant of the samples of the soil surface to the top of the plants. 3.Number of branches/plant. 4. Fresh weight/plant 5. Dry weight/plant. 6. Shedding percentage: It was determined by using the following equation:

Shedding

$$
\text { Shedding } \%=\frac{}{\text { Shedding }+ \text { number of mature pods }} \text { X } 100
$$

At harvest time marketable pods per plant was picked and let to dry up normally and data were recorded for the following traits:7. Number of pods/plant. 8. Seed yield (g)/plant. 9. 100-seed weight (g). 10. Seed yield (ton/ha): whole plants produced from the three inner ridges of each plot were harvested and left to dry in the air, then they were threshed and the seeds (which were at $13 \%$ moisture) were weighted $(\mathrm{kg})$, then converted to $(\mathrm{Kg} / \mathrm{ha})$. 11. Protein \%: Total nitrogen was estimated by the improved Kjeldahl - method according to[14], modified by distilling the ammonia into saturated boric solution and titration in standard acid. Protein \% was estimated by multiplying the total nitrogen values of faba bean flour by 6.25

\subsection{Experimental analysis:}

All obtained data were statistically analyzed according to the technique of analysis of variance (ANOVA) for the split-plot design to each experiment (row spacing), then combined analysis was done between row spacing trails as published by [15]by using "MSTAT-C" computer software package. To test the differences between treatment means, the least significant difference (LSD) method was used at the $5 \%$ level of probability as designated by[16]

\section{RESULTS AND DISCUSSION}

\subsection{Naphthalene Acetic Acid concentration effects:}

The results presented from Tables 1 and 2 clearly revealed that foliar spraying of Naphthalene Acetic Acid (NAA) and Kinetin (Kin) concentrations significantly affected total chlorophyll, plant height $(\mathrm{cm})$, number of branches/plant, number of shedding flowers, shedding $\%$,pods and seeds number/plant,number of seeds/pod, 
seed yield (g)/plant, 100-seed weight (g), seed yield (ton/ha) and protein \%.The results showed that increasing NAA concentrations of $60 \mathrm{ppm}$ significantly increased total chlorophyll, plant height $(\mathrm{cm})$, number of branches/plant, number of shedding flowers, shedding $\%$, pods and seeds number/plant, number of seeds/pod, seed yield (g) /plant, 100-seed weight (g), seed yield (ton/ha) and protein $\%$ in both seasons. From our results, it could be stated that incensing Naphthalene Acetic Acidup to 60 ppm increased total chlorophyll, plant height $(\mathrm{cm})$, branchesnumber/plant, number of shedding flowers, podsnumber/plant, seedsnumber/pod, seedsnumber/plant, seed yield/plant, 100-seed weight (g), seed yield (ton/ha) and protein $\%$ by $11.47,23.92,92.88,20.53,11.87,23.48$, $14.16,24.91,26.15$ and $13.23 \%$, respectively as the average of twoseasons.But, reduced the shedding $\%$ by $11.91 \%$ as the average of two seasons.Foliar application of Naphthalene Acetic Acid increased the growth, viz, plant height, number of branches/plant, leaf area index, dry weight/plant and plant attributes. Plant growth regulators are known to modify the growth and development patterns of plant by exertinga profound effect on various physiological processes and hence regulating seed productivity[17].Application IAA caused a reduction in the flower abscission \%,hence producinga highest number of pod set, seedweight/plant, number of seeds/pod and weight of 100 seeds[7]. The increase in seed yield/plant due to foliar spraying of Naphthalene Acetic Acid could be attributed to the more increases in vegetative growth characters, which might provide more vegetative area and increases pod set\%, reduction in abscission \%, increasing the seed number/pod, as mentioned by[18].These results are in agreement with those described by[6,8,10,11,12].

\subsection{Kinetin (Kin) concentration effects:}

The results presented from Tables 1 and 2 clearly suggested that increasing foliar spraying of Kinetin (Kin) concentrations significantly exaggerated total chlorophyll, plant height $(\mathrm{cm})$, number of branches/plant, number of shedding flowers, shedding \%pods and seeds number/plant,number of seeds/pod, seed yield/plant, 100seed weight (g), seed yield (ton/ha) and protein \%. Our results clearly showed that increasing foliar spraying of Kinetin (Kin) levels up to $45 \mathrm{ppm}$ significantly augmented total chlorophyll, plant height $(\mathrm{cm})$, number of branches/plant, number of shedding flowers, shedding $\%$, pods and seeds number/plant,number of seeds/pod, seed yield/plant, 100-seed weight ( $\mathrm{g}$ ), seed yield (ton/ha) and protein $\%$ percentage.In addition, it could be observed that incensingfoliar spraying of Kinetin (Kin) concentrationsof $45 \mathrm{ppm}$ increased total chlorophyll, plant height $(\mathrm{cm})$, branchesnumber/plant, number of shedding flowers,podsnumber/plant,

seedsnumber/pod, seedsnumber/plant, seed yield/plant, 100-seed weight (g), seed yield (ton/ha) and protein \% by 12.16, 19.39, 61.64, 5.60, 5.56, 6.96, 5.64, 18.75, 13.38 and $4.39 \%$, respectively as average of both seasons. But, reduced the shedding $\%$ by $14.73 \%$ as the average of both seasons. Foliar spraying ofKinetin (Kin) andNaphthalene Acetic Acid(NAA) promote photosynthetic rates, photo assimilates production, fruit set and growth. It could be summarized that the aptitude of cytokines and NAA to mobilize assimilates to the area of request is accountable for enhanced fruit set and seed productivity[19].Foliar spraying with growth regulators, enhanced expression and forms into SOD indicate the possible participation in growth regulators in delaying the membrane deterioration during abscission leading to increased fruit set [20].Seed yields and its attributes i.e. number of pods/plant, pods yield /plant, 100 seed weight, biological yield/plant and protein yield/ha were significantly better with application with $50 \mathrm{mg} / \mathrm{l} \mathrm{IAA}+75 \mathrm{mg} / \mathrm{l} \mathrm{Kinetin[13].} \mathrm{These} \mathrm{results} \mathrm{are}$ in harmony with $[10,11,12,13]$.

\subsection{Interaction Effect:}

From our results, it could have suggested that the interaction among foliar spraying of Naphthalene Acetic Acid (NAA) and Kinetin (Kin) concentrations, results in Tables 1 and 2 designated that plant height $(\mathrm{cm})$, fresh and dry weight/plant and total chlorophyll, number of pods/plant, seed yield/plant significantly affected only in the first season. Whilst, the results in the same Tables showed non-significant effects due to the interaction among foliar spraying of Naphthalene Acetic Acid (NAA) and Kinetin (Kin) concentrations on the number of branches/plant, shedding $\%$ and 100 seed weight in the two seasons. Concerning to the interaction between Naphthalene Acetic Acid (NAA) and Kinetin(Kin) concentrations on seed yield/ha, results in Figs 1 and 2 clearly indicated that this interaction significantly affected on seed yield/ha. From our results, it could be suggested that increasing Naphthalene Acetic Acid (NAA) up to 60 $\mathrm{ppm}$ and Kinetin (Kin) up to $45 \mathrm{ppm}$ increased seed yield/ha by $38.2 \%$ compared without growth regulators foliar application. The growth promoter ofNaphthalene Acetic Acid (NAA) enhances the mobilization of photo assimilates into filling seeds[6]. Seed yield and its attributes i.e.number of pods/plant, pods yield/plant, 100 seed weight, biological yield/plant and seed, proteinyields/ha were significantly improved with foliar spraying at a rate of $50 \mathrm{mg} / \mathrm{l} \mathrm{IAA}+75 \mathrm{mg} / \mathrm{l}$ Kinetin[13]

\section{CONCLUSION}

Accordingly, from above results, it could be suggested that increasing Naphthalene Acetic Acid (NAA) up to 60 ppm and Kinetin (Kin) up to $45 \mathrm{ppm}$ increased seed 
yield/ha by $38.2 \%$ compared without growth regulators foliar application.

\section{REFERENCES}

[1] M.H.Cho, No HK and W.Prinyawiwatkul "Chitosan treatments affect growth and selected quality of sunflower sprouts" J. Food Sci.,2008,73: 570577.https://www.ncbi.nlm.nih.gov/pubmed/1821137 3

[2] M. Michniewiczand B. Rozej "Is the gibberellinlimiting factor for the growth and development of Fusariumculmorum? Acta Physiol.Plant.,1988, 10, 227

236.http://www.sciencedirect.com/science/article/pii /S0944501307000687

[3] P. J.Davies "Plant hormone and their role in plant growth and development. MartinusNijhoff Publ. Dordrecht, Netherlands, Ed. 1987.http://www.gbv.de/dms/bs/toc/016629035.pdf

[4] H.S. Lee "Effect of pre-sowing seed treatment with GA3 and IAA on flowering and yield components of groundnut. Korean J. Crop Sci.,1990, 35(1): 19.https://www.cabdirect.org/cabdirect/abstract/1990 0736802

[5] K.C.Shukla, O.P. Singh and R. K. Samaiya 1997. Effect of foliar spray of plant growth regulators and nutrient complex on productivity of soybean var. JS. 7981. Crop Res.,1997, 13 (1): $213 \quad-$ 215.http://ijagcs.com/wpcontent/uploads/2014/10/1378-1380.pdf

[6] M.ABadawi, A.T. El-Kassaby, A.M. Salama and M.T. Zalama "Influence of Spraying Times of Some Chemical Substances On Yield and Shedding of Field Bean" J. Agric. Sci. Mansoura Univ, 2007,32:7015-

7029.http://www.eulc.edu.eg/eulc v5/Libraries/start. aspx?fn=BrowseByAuthor \&ScopeID $=1 . \&$ AuthorNa me $=$ Badawi+M.A.\%3B+A.T.+El-

Kassaby\%3B+A.M.+Salama+and+M.T.+Zalama

[7] I. S. Ibrahim, 1A.B. Abdel-Razik and M. Ebeed Naglaa "Effect of some plant growth regulators on biochemical gene Expression, growth and yield of faba bean" Pak. J. Biotechnology, 2007, 4 (1-2) 4764.http://www.pjbt.org/uploads/PJBT-VOL-4-NO-12-OF-YEAR-2007\%20(7).pdf

[8] S.H. Shah "Effect of kinetin spray on growth and productivity of black cumin plants" RussianJ. Plant Physiol.,2007,54:702-

705.https://link.springer.com/article/10.1134/S10214 43707050202

[9] H.S.Khafaga, A.H. Raeefa, M.M. Hala and S.A. Alaa "Response of two faba bean cultivars to application of certain growth regulators under salinity stress condition at Siwa Oasis:1-Growth traits, yield and yield components". Proceedings of the $4^{\text {th }}$ Conference on Recent Technologies in Agriculture, Nov. 3-4, 2009, Cairo, Giza, Egypt, pp: 236-249.

http://www.aensiweb.com/old/jasr/jasr/2011/18831889.pdf

[10] M.M. Ammanullah, S. Sekar and S. Vicent"Plant growth substances in crop production" Asian J. Plant Sci., 2010, 9: 215222.http://scialert.net/fulltext/?doi=ajps.2010.215.22 2

[11] M.A. Nosser"Effect of Some Foliar Application on Yield and Its Components in Broad Bean (Vicia faba L.). Egypt. J. Agric. Res.,2011, 89 (3):10711087.http://www.arc.sci.eg/ejar/UploadFiles/Publica tions $/ 1118913 \% \mathrm{D} 8 \% \mathrm{~A} 7 \% \mathrm{D} 9 \% 84 \% \mathrm{D} 8 \% \mathrm{~A} 8 \% \mathrm{D} 8 \%$ AD\%D8\%AB\%20\%D8\%A7\%D9\%84\%D8\%AB\% D8\%A7\%D9\%86\%D9\%89\%20\%D8\%A7\%D9\%84 $\% \mathrm{D} 8 \% \mathrm{~A} 8 \% \mathrm{D} 8 \% \mathrm{~B} 3 \% \mathrm{D} 8 \% \mathrm{~A} 7 \% \mathrm{D} 8 \% \mathrm{AA} \% \mathrm{D} 9 \% 8 \mathrm{~A}$ \%D9\%86.pdf

[12] A.A.Kandil, A.E. Sharief and A.S.A. Mahmoud "Reduction of Flower Dropping in Some Faba Bean Cultivars by Growth Regulators Foliar Application. Journal of Applied Sciences Research, 2011, 7(12): $1883-$

1889.http://www.aensiweb.com/old/jasr/jasr/2011/1 883-1889.pdf

[13] M.Sh. Sadak, Mona G. Dawood, B.A. Bakry and M.F. El-Karamany "Synergistic Effect of Indole Acetic Acid and Kinetin on Performance, Some Biochemical Constituents and Yield of Faba Bean Plant Grown under Newly Reclaimed Sandy Soil" World Journal of Agricultural Sciences, 2013, 9 (4): 335 -

344.https://www.idosi.org/wjas/wjas9(4)13/5.pdf

[14] A.O.A.C. "Official Methods of Analysis. 18 ${ }^{\text {th }}$ Ed. Association of Official Analytical Chemists, 2007 Inc., Gaithersburg, MD, Method 04.http://www.eoma.aoac.org/

[15]Gomez, K.A. and A.A. Gomez1991. Statistical Procedures in Agricultural Research, John Wiley and Sons, New York.http://pdf.usaid.gov/pdf_docs/PNAAR208.pdf

[16] G.W. Snedecor and W. G. Cochran "Statistical Methods, 7th Ed.,1980, Ames, IA: The Iowa State University

Press.https://www.amazon.com/Statistical-MethodsSeventh-isbn-0813815606/dp/B0012S4NIE

[17] J.W. Patrick "Assimilate partitioning in relation to crop productivity" Hort. Sci.,1988, 23: 3340.http://journal.ashspublications.org/content/118/6/ 820.full.pdf 
[18] M.A. Abd-El-Fattah "Effect of phosphorus, boron, GA3, and their interaction on growth, flowering, pod setting, abscission and both green pod and seed yields of broad bean (Vicia faba, L.) plants. Alexandria J. of Agric. Res.,1997, 42(3): 311332.http://agris.fao.org/agrissearch/search.do?recordID=EG2000-02413

[19] R.N. Arteca "Plant Growth Substances". Chapman \& Hall, Dept. BC, 115 Fifth,1996, Avenue, New
Pp.

205

York

.http://www.springer.com/cn/book/9780412039119

[20] M.Djanaguiraman, D. Durga Devi, J. Annie Sheeba U. Bangarusamy and R. C. Babu"Effect of oxidative stress on abscission of tomato fruits and its regulation by Nitrophenols"Tropcal Agriculture Res.,2004, 16:

25

36.https://www.pgia.ac.lk/files/Annual_congress/jou rnel/v16/EffectofOxidat.pdf

Table.1: Mean of plant height (cm), No. of branches/plant, fresh and dry weight/plant and total chlorophyll as affected by Naphthalene Acetic Acid (NAA) and Kinetin (Kin) concentrations during 2014/2015 and 2015/2016 seasons.

\begin{tabular}{|c|c|c|c|c|c|c|c|c|c|c|}
\hline \multirow{2}{*}{$\begin{array}{c}\text { Treatmen } \\
\text { ts }\end{array}$} & \multicolumn{2}{|c|}{ Plant height (cm) } & \multicolumn{2}{|c|}{$\begin{array}{c}\text { No. of } \\
\text { branches/plant }\end{array}$} & \multicolumn{2}{|c|}{$\begin{array}{c}\text { Fresh weight/plant } \\
\text { (g) }\end{array}$} & \multicolumn{2}{|c|}{ Dry weight/plant (g) } & \multicolumn{2}{|c|}{ Total chlorophyll } \\
\hline & $\begin{array}{c}2014 / 201 \\
5\end{array}$ & $\begin{array}{c}2015 / 201 \\
6\end{array}$ & $\begin{array}{c}2014 / 201 \\
5\end{array}$ & $\begin{array}{c}2015 / 201 \\
6\end{array}$ & $\begin{array}{c}2014 / 201 \\
5\end{array}$ & $\begin{array}{c}2015 / 201 \\
6\end{array}$ & $\begin{array}{c}2014 / 201 \\
5\end{array}$ & $\begin{array}{c}2015 / 201 \\
6\end{array}$ & $\begin{array}{c}2014 / 201 \\
5\end{array}$ & $\begin{array}{c}2015 / 201 \\
6\end{array}$ \\
\hline \multicolumn{11}{|c|}{ A. Nitrogen fertilizer rates: } \\
\hline $\begin{array}{l}0 \mathrm{ppm} \\
\text { NAA }\end{array}$ & 97.1 & 100.8 & 4.24 & 4.28 & 671.05 & 672.48 & 167.70 & 168.85 & 40.82 & 41.86 \\
\hline $\begin{array}{l}20 \mathrm{ppm} \\
\text { NAA }\end{array}$ & 102.6 & 108.7 & 5.31 & 5.42 & 794.05 & 781.57 & 182.45 & 179.51 & 42.85 & 43.28 \\
\hline $\begin{array}{l}40 \mathrm{ppm} \\
\text { NAA }\end{array}$ & 106.7 & 112.1 & 5.35 & 5.55 & 820.18 & 831.58 & 192.79 & 197.25 & 44.11 & 46.13 \\
\hline $\begin{array}{l}60 \mathrm{ppm} \\
\text { NAA }\end{array}$ & 109.2 & 114.3 & 5.49 & 5.71 & 864.22 & 870.83 & 207.95 & 215.57 & 46.71 & 47.11 \\
\hline F-test & $*$ & $*$ & $*$ & $*$ & $*$ & $*$ & $*$ & $*$ & $*$ & $*$ \\
\hline L.S.D. $5 \%$ & 0.8 & 0.8 & 0.05 & 0.04 & 5.28 & 3.06 & 0.51 & 0.91 & 0.15 & 0.16 \\
\hline \multicolumn{11}{|c|}{ B. Phosphorus fertilize rates: } \\
\hline 0 ppm kin & 97.2 & 101.5 & 4.49 & 4.56 & 701.88 & 712.40 & 183.57 & 184.15 & 42.71 & 42.91 \\
\hline $\begin{array}{l}15 \text { ppm } \\
\text { kin }\end{array}$ & 100.6 & 106.8 & 5.06 & 5.22 & 799.81 & 793.16 & 186.61 & 188.8 & 43.33 & 44.29 \\
\hline $\begin{array}{l}30 \mathrm{ppm} \\
\text { kin }\end{array}$ & 107.0 & 112.1 & 5.23 & 5.48 & 809.68 & 810.41 & 188.59 & 190.81 & 43.89 & 45.14 \\
\hline $\begin{array}{l}45 \mathrm{ppm} \\
\text { kin }\end{array}$ & 110.7 & 115.5 & 5.59 & 5.65 & 839.44 & 840.51 & 192.12 & 197.41 & 44.56 & 46.09 \\
\hline F-test & $*$ & $*$ & $*$ & $*$ & $*$ & $*$ & $*$ & $*$ & $*$ & $*$ \\
\hline L.S.D. $5 \%$ & 0.5 & 0.5 & 0.05 & 0.03 & 3.89 & 1.84 & 0.38 & 0.48 & 0.08 & 0.19 \\
\hline \multicolumn{11}{|c|}{ Interaction AXB } \\
\hline F-test & $*$ & N.S. & NS. & N.S. & $*$ & N.S. & $*$ & N.S. & $*$ & N.S. \\
\hline
\end{tabular}


Table.2: Mean of shedding percentage, No. of pods/plant, 100-seed weight seed yield/plant and per hectare and protein percentage as affected by Naphthalene Acetic Acid (NAA) and Kinetin (Kin) concentrations during 2014/2015 and 2015/2016 seasons.

\begin{tabular}{|c|c|c|c|c|c|c|c|c|c|c|c|c|}
\hline \multirow{2}{*}{ Treatments } & \multicolumn{2}{|c|}{ Shedding \% } & \multicolumn{2}{|c|}{ No. of pods/plant } & \multicolumn{2}{|c|}{$\begin{array}{c}\text { 100-seed weight } \\
\text { (g) }\end{array}$} & \multicolumn{2}{|c|}{$\begin{array}{c}\text { Seed yield/plant } \\
\text { (g) }\end{array}$} & \multicolumn{2}{|c|}{ Seed Yield $t / h a$} & \multicolumn{2}{|c|}{ Protein \% } \\
\hline & $\begin{array}{l}2014 / 2 \\
015\end{array}$ & $\begin{array}{l}2015 / 2 \\
016\end{array}$ & $\begin{array}{c}2014 / 2 \\
015\end{array}$ & $\begin{array}{l}2015 / 2 \\
016\end{array}$ & $\begin{array}{c}2014 / 2 \\
015\end{array}$ & $\begin{array}{l}2015 / 2 \\
016\end{array}$ & $\begin{array}{l}2014 / 2 \\
015\end{array}$ & $\begin{array}{l}2015 / 2 \\
016\end{array}$ & $\begin{array}{l}2014 / 2 \\
015\end{array}$ & $\begin{array}{l}2015 / 2 \\
016\end{array}$ & $\begin{array}{l}2014 / 2 \\
015\end{array}$ & $\begin{array}{l}2015 / 2 \\
016\end{array}$ \\
\hline \multicolumn{13}{|c|}{ A. Nitrogen fertilizer rates: } \\
\hline 0 ppm NAA & 85.31 & 85.55 & 18.65 & 19.53 & 94.32 & 94.88 & 81.81 & 82.79 & 4.276 & 4.301 & 26.15 & 26.75 \\
\hline $\begin{array}{l}20 \mathrm{ppm} \\
\text { NAA }\end{array}$ & 83.66 & 83.74 & 21.69 & 22.83 & 98.75 & 99.45 & 88.45 & 88.85 & 4.746 & 4.801 & 27.66 & 28.50 \\
\hline $\begin{array}{l}40 \mathrm{ppm} \\
\text { NAA }\end{array}$ & 79.59 & 80.77 & 23.01 & 24.03 & 103.67 & 105.75 & 96.78 & 98.11 & 5.122 & 5.100 & 28.62 & 29.45 \\
\hline $\begin{array}{l}60 \mathrm{ppm} \\
\text { NAA }\end{array}$ & 71.61 & 78.89 & 24.55 & 25.35 & 110.90 & 111.16 & 109.11 & 110.26 & 5.791 & 5.822 & 30.31 & 30.36 \\
\hline F-test & $*$ & $*$ & $*$ & $*$ & $*$ & $*$ & $*$ & $*$ & $*$ & $*$ & $*$ & $*$ \\
\hline L.S.D. 5\% & 0.25 & 0.35 & 0.26 & 0.15 & 0.27 & 0.61 & 0.18 & 0.73 & 0.079 & 0.119 & 0.12 & 0.25 \\
\hline \multicolumn{13}{|c|}{ B. Phosphorus fertilize rates: } \\
\hline 0 ppm kin & 85.19 & 84.51 & 21.50 & 22.01 & 99.76 & 100.06 & 86.16 & 87.40 & 4.542 & 4.578 & 27.72 & 27.96 \\
\hline 15 ppm kin & 84.44 & 83.96 & 21.83 & 22.84 & 100.66 & 101.48 & 89.07 & 91.17 & 4.769 & 4.799 & 27.80 & 28.65 \\
\hline 30 ppm kin & 80.36 & 83.42 & 22.14 & 23.03 & 102.05 & 103.15 & 94.18 & 94.69 & 4.993 & 4.999 & 28.30 & 29.13 \\
\hline 45 ppm kin & 70.79 & 73.91 & 22.45 & 23.76 & 105.05 & 106.68 & 106.73 & 106.76 & 5.596 & 5.626 & 28.92 & 29.31 \\
\hline F-test & $*$ & $*$ & $*$ & $*$ & $*$ & $*$ & $*$ & $*$ & $*$ & $*$ & $*$ & $*$ \\
\hline L.S.D. 5\% & 0.24 & 0.23 & 0.15 & 0.08 & 0.37 & 0.19 & 0.36 & 0.46 & 0.196 & 0.177 & 0.10 & 0.15 \\
\hline \multicolumn{13}{|c|}{ Interaction $\mathrm{AXB}$} \\
\hline F-test & N.S. & N.S. & $*$ & N.S. & N.S. & N.S. & $*$ & N.S. & $*$. & $*$ & $*$ & N.S. \\
\hline
\end{tabular}

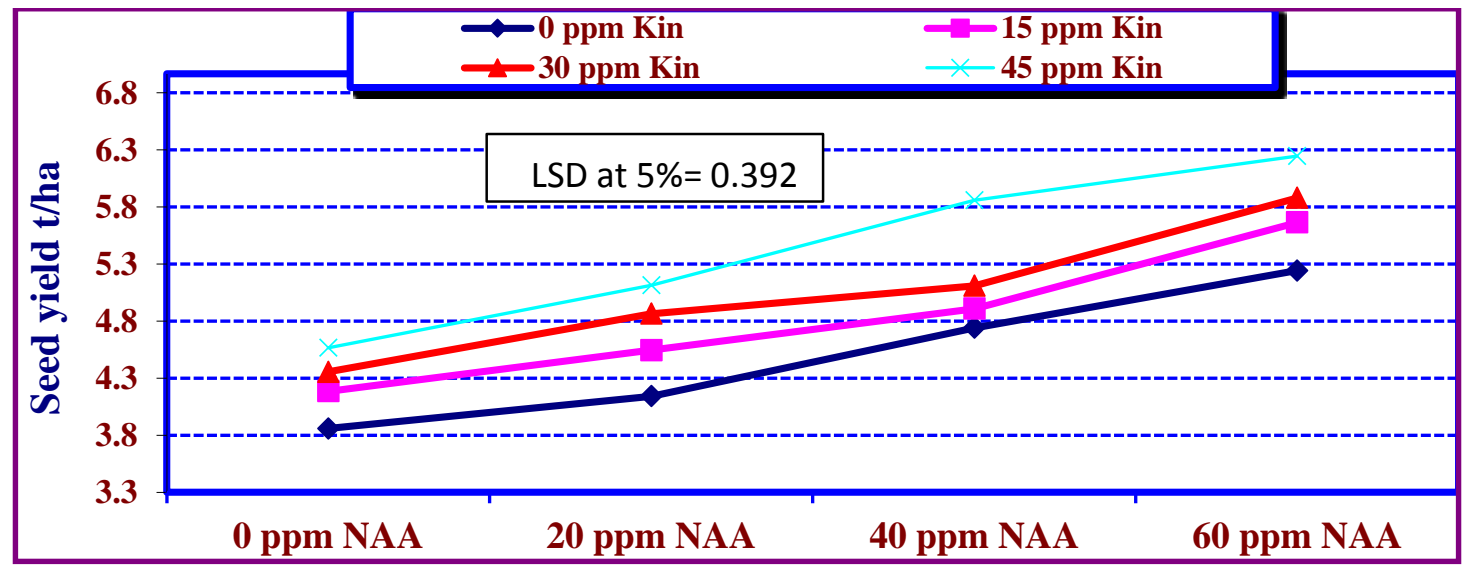

Fig.1: Seed yield t/ha as affected by the interaction between NAA and Kin concentrations during 2014/2015 season.

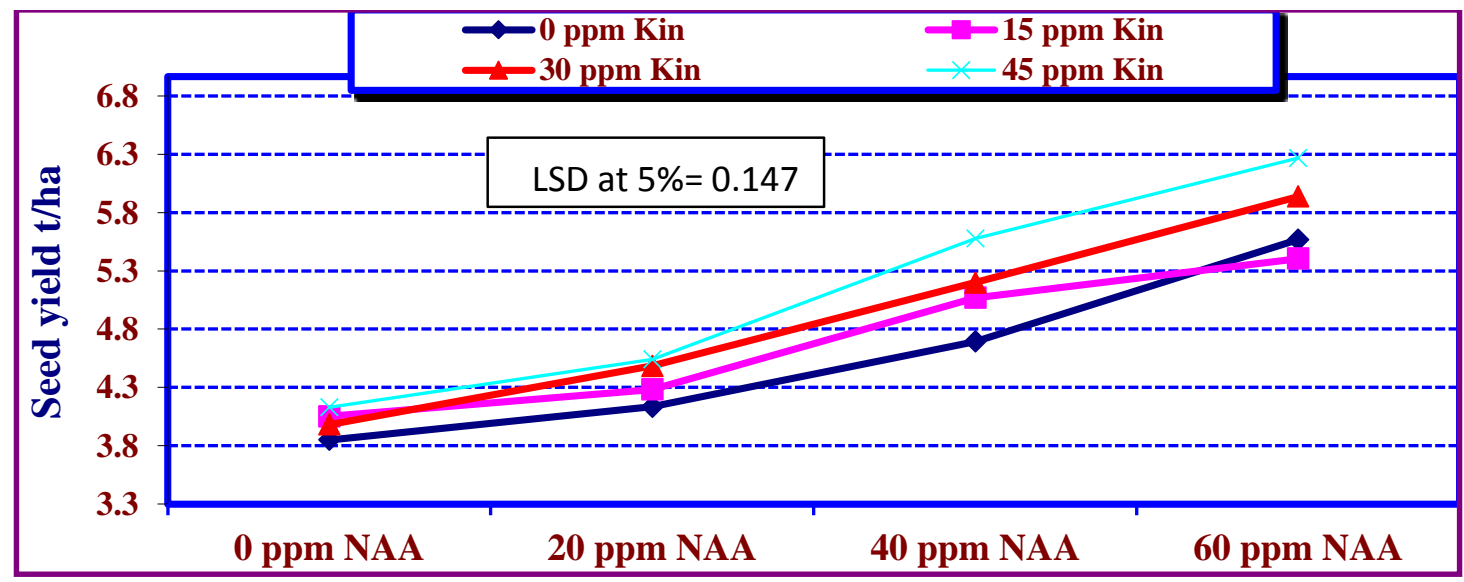

Fig.2: Seed yield t/ha as affected by the interaction between NAA and Kin concentrations during 2015/2016 season 